\title{
Komersialisasi Pendidikan
}

\author{
Asmirawanti \\ Sulfasyah \\ Universitas Muhammadiyah Makassar \\ sulfasyah@unismuh.ac.id \\ Jamaluddin Arifin \\ Universitas Muhammadiyah Makassar \\ jamaluddinarifin@unismuh.ac.id
}

\begin{abstract}
ABSTRAK
Pendidikan berpengaruh terhadap kehidupan suatu bangsa untuk masuk dan memperoleh dampak-dampak yang ditimbulkan arus globalisasi tersebut. Pendidikan di saat ini telah terjebak dalam arus kapitalisasi atau komersialisasi pendidikan. Penelitian ini bertujuan untuk (i) Mengetahui bentuk komersialisasi pendidikan (ii) Mengetahui dampak komersialisasi pendidikan terhadap anak putus sekolah di Kelurahan Pabiringa Kecamatan Binamu Kabupaten Jeneponto. Jenis penelitian ini merupakan penelitian kualitatif yang bersifat deskriptif. Penentuan informan dilakukan dengan teknik purposive sampling. Sumber data yang digunakan yaitu data primer dan sekunder. Dengan menggunakan teknik pengumpulan data malalui observasi, wawancara dan dokumentasi. Teknik analisi data yang digunakan adalah secara kualitatif deskriptif. Hasil penelitian ini menunjukkan bahwa, 1) Bentuk Komersialisasi pendidikan yang terjadi yaitu (a) biaya pendidikan mahal, (b) banyaknya pungutan-pungutan lembaga pendidikan, (c) perdagangan di dunia pendidikan. 2) Dampak positif adanya komersialisasi pendidikan bagi masyarakat yaitu (a) beban pemerintah membiayai pendidikan semakin berkurang, (b) lembaga pendidikan semakin kompetitif sehingga meningkatkan fasilitas dan mutu pendidikan, (c) menambah keuntungan dan pemasukan kas lembaga pendidikan, sedangkan dampak negatifnya yaitu (a) pendidikan semakin mahal (b) pendidikan sebagai ladang bisnis, (c) gejala stigmatisasi dan diskriminasi antara kaya dan miskin, (d) rantai kemiskinan yang sulit diputuskan melalui pendidikan, (e) tercipta privatisasi pendidikan, (f) perubahan misi pendidikan dari budaya akademik menjadi budaya ekonomi.
\end{abstract}

Kata Kunci : Penelitian Sosial Budaya,Komersialisasi Pendidikan,Pendidikan Mahal.

\section{PENDAHULUAN}

Pendidikan selain sebagai suatu pembentuk watak atau kepribadian juga mempersiapkan sumber daya manusia yang handal serta dapat dipertanggung jawabkan. Pendidikan berpengaruh terhadap kehidupan suatu bangsa untuk masuk dan memperoleh dampak-dampak yang ditimbulkan arus globalisasi tersebut. Dampak yang ditimbulkan arus globalisasi tersebut telah melanda di bidang kehidupan masyarakat bangsa Indonesia pada khususnya, baik bidang sosial, politik, ekonomi, budaya bahkan dalam bidang pendidikan Pendidikan di saat ini telah terjebak dalam arus kapitalisasi yang dalam istilah lain bernama komersialisasi pendidikan.Adanya biaya pendidikan yang tidak murah 
berakibat pada banyaknya anak yang berasal dari kelas ekonomi bawah sulit mendapatkan akses pendidikan yang lebih bermutu. Sekolah kemudian menerapkan aturan seperti pasar yang berimplikasi pada visiologis pendidikan yang salah. Keberhasilan pendidikan hanya didasari pada besarnya jumlah lulusan sekolah yang dapat diserap oleh sektor industri. Pendidikan semacam ini tidak untuk menjadikan manusiamanusia melek sosial, padahal sebetulnya tujuan pendidikan untuk mengembangkan intelektual yang ada pada siswa (Andrias Harefa, 2005: 151).

Dunia pendidikan Indonesia saat ini dianggap belum dapat mencapai titik keberhasilan yang diharapkan bersama. Permasalahan yang dihadapi oleh dunia pendidikan Indonesia begitu banyak dan rumit sehingga solusi yang dilakukan untuk keluar dari permasalahan tersebut tidaklah mudah. Permasalahan yang tidak kalah penting yaitu menyangkut masalah biaya pendidikan saat ini yang semakin mahal. Setiap jenjang pendidikan membutuhkan biaya yang tidak sedikit, bahkan untuk tingkat sekolah dasar biaya pendidikan yang harus dikeluarkan hampir mendekati atau bahkan jauh lebih mahal daripada sekolah lanjutan sehingga menyaingi biaya pendidikan untuk perguruan tinggi. Banyak pungutan-pungutan yang ditarik oleh sekolah sehingga biaya yang dikeluarkan oleh peserta didik semakin banyak dan mahal setiap tahunnya.

Pendidikan di Indonesia masih merupakan investasi yang mahal sehingga diperlukan perencanaan keuangan serta persiapan dana pendidikan sejak dini. Masyarakat Kelurahan Pabiringa yang mempunyai kepedulian tinggi terhadap dunia pendidikan, sehingga harus memiliki perencanaan keuangan sejak awal, agar pendidikan anak terus berlanjut dan tidak putus sekolah.

\section{KAJIAN TEORI}

Pendidikan adalah suatu proses pembaharuan makna pengalaman, baik dalam pergaulan biasa atau pergaulan orang dewasa dengan orang muda, yang sengaja dan dilembagakan untuk menghasilkan kesinambungan sosial". pendidikan dapat dipergunakan untuk membantu penduduk dalam meningkatkan taraf hidupnya ke tingkat yang lebih tinggi melalui usaha mereka sendiri (Ravik Karsidi, 2005: 185). Pendidikan adalah usaha yang sadar dilakukan orang dewasa untuk membawa anak didik ke arah kedewasaan, baik dewasa jasmani maupun rohani yang mampu berdiri sendiri dibawah hidup bermasyarakat dan bertanggung jawab terhadap kehidupan masyarakat bangsa dan negara. Sehingga, peserta didik secara aktif dapat mengembangkan potensi diri untuk memiliki kekuatan spiritual keagamaan, emosional, pengendalian diri, 
Proses memanusiakan manusia dalam pendidikan dianggap sebagai rangkaian proses pemberdayaan potensi dan kompetensi individu untuk menjadi manusia berdaya yang berkualitas sepanjang hayat. Pendidikan mampu mengangkat kehidupan manusia ke dalam kelas sosial yang lebih tinggi seperti yang diungkapkan oleh Clark yang menyatakan bahwa pendidikan dapat dipergunakan untuk membantu penduduk dalam meningkatkan taraf hidupnya ke tingkat yang lebih tinggi melalui usaha mereka sendiri (Ravik Karsidi, 2005: 185). Selain itu, dalam pasal 1 Undang-undang No. 20/2003 tentang Sistem Pendidikan Nasional, disebutkan definisi pendidikan diartikan sebagai berikut:"Pendidikan adalah usaha sadar dan terencana untuk mewujudkan suasana belajar dan proses pembelajaran agar peserta didik secara aktif mengembangkan potensi dirinya untuk memiliki kekuatan spiritual keagamaan, pengendalian dir, kepribadian, kecerdasan, akhlak mulia serta keterampilan yang diperlukan dirinya,masyarakat, bangsa dan Negara".

Di dalam era global saat ini terjadi proses globalisasi yang menyatukan kehidupan umat manusia. masyarakat merupakan salah satu pemegang hak maka tujuan lembaga-lembaga pendidikan harus pula menampung yang diinginkan oleh masyarakat dan bukan hanya menampung yang diinginkan oleh birokrasi. Di dalam kaitan ini perlu ada lembaga atau struktur organisasi di dalam lembaga-lembaga pendidikan dimana masyarakat ikut serta berpartisipasi. Pendidikan tidak terlepas dari perubahan social di dalam masyarakat demokratis. Hal ini berarti bahwa pendidikan dilahirkan sebagai bagian dari kehidupan social dan oleh sebab, kehidupan social tersebut merupakan suatu realitas yang dinamis,maka pendidikan itupun haruslah dinamis sifatnya. Pendidikan yang dinamis adalah hasil dari manajemen yang dinamis pula. fungsi pendidikan untuk masyarakat dalam lingkungan Negara antara lain mengembangkan kemampuan dan membentuk watak serta peradaban bangsa yang bermartabat dalam rangka mencerdaskan kehidupan bangsa. Fungsi pendidikan menurut Broon dalam Pidarta ( $2000: 171$ ) adalah: 1) Transmisi budaya, 2) Meningkatkan integrasi sosial atau masyarakat, 3) Mengadakan seleksi dan alokasi tenaga kerja melalui pendidikan itu sendiri, 4) Mengembangkan kepribadian

Hakikat pendidikan adalah memanusiakan manusia. Memanusiakan-manusia atau proses humanisasi melihat sebagai suatu keseluruhan di dalam eksistensinya. Seperti yang telah di uraikan, eksistensi manusia ditentukan oleh relasi moralnya terhadap empat hakikat kehidupannya, atau terhadap hak asasi manusia yang mempunyai implikasi kewajiban-kewajiban tertentu sehubungan dengan relasi eksistensialnya tersebut. 
Proses pendidikan sebagai humanisme menunjukkan,bahwa pendidikan bukanlah suatu yang telah tertentu ( given ), tetapi merupakan suatu aksi yang berkelanjutan. Proses pendidikan merupakan suatu kesatuan dari aksi refleksi-aksi. Inilah cirri khas dari pendidikan sebagai ilmu praksis. Habibie dalam Darmaningtyas (2005: 257), bahwa "komersialisasi pendidikan telah mengantarkan pendidikan sebagai instrument untuk melahirkan buruh-buruh bagi sektor industri, bukan sebagai proses pencerdasan dan pendewasaan masyarakat". Adanya komersialisasi pendidikan telah menggambarkan keadaan pendidikan saat ini bahwa pendidikan lebih mengarah kepada praktik pendidikan layaknya lembaga penghasil mesin yang siap mem-supplay pasar industri dan diukur secara ekonomis. Pendidikan menjadi hal yang eksklusif dan jauh dari masyarakat umum bahkan hanya bisa dinikmati oleh kalangan tertentu (elit penguasa).

Komersialisasi pendidikan menurut Agus Wibowo (2008 : 111) juga mengacu pada dua pengertian yang berbeda bahwa :

1) Komersialisasi hanya mengacu pada lembaga pendidikan dengan program pendidikan serta perlengkapan yang serba mahal. Selain itu, komersialisasi pendidikan juga mengacu pada lembaga-lembaga pendidikan yang hanya mementingkan penarikan uang pendaftaran dan uang sekolah saja, tetapi mengabaikan kewajiban yang harus diberikan kepada siswa.

2) Komersialisasi pendidikan yang mengacu pada lembaga pendidikan dengan program pembiayaan sangat mahal. Pada pengertian ini, pendidikan hanya dapat dinikmati oleh sekelompok masyarakat ekonomi kuat, sehingga lembaga tersebut tidak dapat disebut dengan istilah komersialisasi karena mereka memang tidak memperdagangkan pendidikan, tetapi uang pembayaran sekolah sangat mahal. Pemungutan biaya tinggi hanya untuk memfasilitasi jasa pendidikan serta menyediakan infrastruktur pendidikan bermutu, seperti menyediakan fasilitas teknologi informasi, laboratorium dan perpustakaan yang baik serta memberikan kepada para guru atau dosen gaji menurut standar. Sedangkan untuk sisa anggaran yang diperoleh, digunakan untuk menanamkan kembali bentuk infrastruktur pendidikan. Komersialisasi pendidikan jenis ini tidak akan mengancam idealisme pendidikan nasional atau idealisme Pancasila, tetapi dapat menimbulkan diskriminasi dalam pendidikan nasional.

3) Komersialisasi pendidikan yang mengacu pada lembaga-lembaga pendidikan yang hanya mementingkan uang pendaftaran dan uang kuliah, tetapi mengabaikan kewajiban-kewajiban pendidikan. Komersialisasi pendidikan ini biasa dilakukan oleh 
lembaga atau sekolah-sekolah yang menjanjikan pelayanan pendidikan, tetapi tidak sepadan dengan uang yang pungut.

Ketidak-adilan dalam bidang ekonomi sangat tampak dalam masyarakat kapitalisme liberal. Untuk menutupi ketimpangan ini negara menarik pajak besar kepada para kapitalis dan memberi santunan kepada mereka yang menganggur dan miskin. Kompensasi seperti ini dianggap sudah cukup untuk menutupi keslahan sistem Kapitalisme Liberal. Karl Marx dan pengikutnya mengkritik sistem ini dan berusaha mengantikannya dengan sistem Sosialisme yang dianggapnya lebih adil. Namun, dalam kenyataannya, negara-negara yang menganut sistem Sosialisme juga tumbang karena tidak mempu membawa kesejahteraan bagi rakyatnya.

Kapitalisme telah menunjukkan keunggulannya dalam bersaing dengan sistem sosialisme, tetapi kapitalisme belum dapat mewujudkan keadilan sosial ekonomi dalam masyarakat dunia. Di dunia sekarang ini sudah maju ilmu pengetahuan dan teknologinya, tetapi masih terdapat banyak negara miskin, dan hanya beberapa negara yang kaya. Negara miskin masih punya peluang untuk mengejar ketinggalannya apabila mempunyai jalan yang tepat. Kapitalisme Organis sebagai sistem ekonomi yang memperhatikan kepentingan semua pihak dalam kegiatan ekonomi dapat memperbaiki nasib orang miskin. Sistem ekonomi Kapitalisme Organis menata ekonomi sebagai organisme hidup

\section{METODE PENELITIAN}

Jenis penelitian yang dilakukan penelitian kualitatif yang bersifat deskriptif, yang berupaya untuk menyelidiki suatu fenomena sosial yang terdapat dalam lingkungan kelurahan Pabiringa kecamatan binamu kabupaten jeneponto. Informan dalam penelitian ini terdiri dari anak putus sekolah dan para pendidik. Penentuan informan dilakukan dengan teknik purposive sampling. Sumber data yang digunakan yaitu data primer dan sekunder. Dengan menggunakan teknik pengumpulan data malalui observasi, wawancara dan dokumentasi. Teknik analisis data yang digunakan adalah secara kualitatif deskriptif. Analisis ini dilakukan dengan cara menyusun dan mereduksi data, mendisplay data yang dikumpulkan dari berbagai pihak dan kemudian memberikan verifikasi untuk disimpulkan.

\section{PEMBAHASAN}

Pendidikan merupakan salah satu kebutuhan yang tidak dapat ditinggalkan oleh semua orang sebagai bagian dari suatu negara. Secara teknis, jika seseorang bertanggung 
jawab terhadap diri sendiri berarti suatu upaya untuk memberikan satu kondisi terbaik. Kondisi terbaik untuk diri sendiri berarti kemampuan yang memungkinkan seseorang menghadapi setiap masalah dengan cara dan hasil yang sebaik-baiknya. Hal inilah yang kemudian menjadi citra khusus yang harus dimiliki oleh setiap orang sehingga eksistensinya dalam hidup diakui oleh masyarakat luas. Kenyataan di masyarakat bahwa individu-individu dengan tingkat pendidikan yang tinggi sering menjadi sosok istimewa dalam kehidupan bermasyarakat.

Pendidikan merupakan kebutuhan paling utama dalam kehidupan manusia sehingga proses pendidikan dan kegiatan pembelajaran harus terencana dan dalam penyusunannya tidak dapat terlepas dari factor pembiayaan. Hal ini disebabkan karena di dalam pelaksanaannya ada banyak hal yang harus dilakukan, disiapkan dan selanjutnya diadakan agar proses pendidikan dapat berlangsung dengan lancar. Berbagai hal harus disiapkan dan disediakan oleh semua pihak, khususnya dalam hal sarana prasarana pendidikan serta pembelajaran sehingga dibutuhkan dana yang tidak sedikit. Dengan dana tersebut maka kebutuhan sarana prasarana serta operasional pendidikan dapat disediakan oleh sekolah.Pendidikan menjadi bagian dari berbagai kepentingan atau keinginan masyarakat yang tidak lepas dari kesejarahan dan cita-cita suatu negara bangsa dalam perubahan besar dunia untuk mencapai kemajuannya.

Pendidikan menjadi bagian dari berbagai kepentingan atau keinginan masyarakat yang tidak lepas dari kesejarahan dan cita-cita suatu negara bangsa dalam perubahan besar dunia untuk mencapai kemajuannya. Masalah itulah yang sedang dialami oleh bangsa Indonesia saat ini. Lembaga-lembaga pendidikan Indonesia saat ini, berlombalomba untuk menaikkan biaya pendidikan dengan alasan, karena semakin tinggi biaya pendidikan yang harus dipenuhi sekarang ini .Peningkatan biaya pendidikan merupakan tujuan utama dari lembaga-lembaga pendidikan, tetapi tidak diikuti adanya pelayanan pendidikan yang maksimal dalam peningkatan mutu pendidikan yang ahsilnya tetap tidak meningkat. Dampak adanya globalisasi telah memberi pengaruh terhadap pendidikan di Indonesia, karena telah mengancamnya kearah orientasi pasar.

Menurut paham kapitalisme dalam pemikiran Marx,kapitalisme merupakan suatu bentuk masyarakat kelas yang distrukturisasikan dengan cara khusus dimana manusia diorganesasikan untuk produksi kebutuhan hidup. Keadaan tersebut merupakan hubungan produksi sekolah dominan yang cenderung mempunyai kesempatan untuk menguasai alat produksi untuk melanggengkan kekuasaan penindasan yang komersial. Hal ini jelas bahwa lembaga pendidikan atau sekolah-sekolah tersebut merupakan penguasa (kelas 
kapitalis) yang kemudian akan mengambil tenaga buruh demi kepentingannya yang tidak lain adalah masyarakat yang menyekolahkan anaknya terutama bagi yang kurang mampu.

Walaupun terdapat program pemerintah berupa dana Bantuan Operasional Sekolah (BOS) yang dicanangkan untuk meringankan beban peserta didik terutama dijenjang pendidikan Sekolah Dasar maupun Sekolah Menengah, tetapi pada kenyataannya kurang membantu meringankan beban peserta didik. Dalam perubahan masyarakat inilah yang kemudian memuculkan kelas-kelas yaitu kelas atas yang memegang kekuasaan untuk mengendalikan dan menindas kelas bawah. Selain tingginya Sumbangan Penyelenggaraan Pendidikan (SPP) masih banyak pungutan-pungutan diluar pungutan wajib seperti buku-buku pelajaran, maupun kegiatan-kegiatan di luar sekolah juga. Dengan demikian, walaupun bantuan dari pemerintah sudah digalakkan untuk meringankan beban peserta didik, tetapi biaya pendidikan masih mahal menunjukkan bahwa masyarakat masih kurang mampu membiayai pendidikan karena tingkat ekonominya relative rendah dan dituntut untuk membiayai pelaksanaan pendidikan yang tinggi.

Komersialisasi pendidikan dianggap sebagai misi lembaga pendidikan modern mengabdi kepada kepentingan pemilik modal dan bukan sebagai sarana pembebasan bagi kaum tertindas". Akibatnya pendidikan yang humanisasi tidak tercapai dalam proses pendidikan karena adanya komersialisasi pendidikan menurut Satriyo Brojonegoro hanya mampu dinikmati oleh pihak-pihak tertentu yang memiliki modal untuk mengakses pendidikan ( Darmaningtyas, $2005: 31$ ). Namun, lembaga tersebut tidak dapat disebut dengan istilah komersialisasi pendidikan karena lembaga pendidikan memang tidak memperdagangkan pendidikan, tetapi uang pembayaran sekolah yang sangat mahal.

Pendidikan mahal saat ini sudah menjadi trend tersendiri di dunia pendidikan, pendidikan diibaratkan sebagai pasar atau supermarket yang menyediakan berbagai barang yang diperlukan oleh pelanggan, sedangkan pendidik (guru atau dosen) sebagai kasir yang selalu melayani pelanggan yaitu peserta didik mereka sendiri. Biaya pendidikan yang mahal sebenarnya mempunyai pengaruh besar terhadap kualitas lembaga pendidikan di Indonesia, apalagi di era globalisasi saat ini segala sesuatu banyak dinilai dengan materi. Akibatnya sekolah negeri favorit saat ini hampir tidak berbeda jauh dengan sekolah swasta dalam masalah biaya pendidikan. Lembaga pendidikan saling bersaing (kompetifif) dalam masalah mutu dan fasilitas untuk menarik peminat yang banyak sehingga biaya pendidikannya pun semakin mahal. 
Praktik lembaga pendidikan formal yang seharusnya menjadi transfomasi dan konservasi nilai-nilai budaya telah terpengaruh oleh kepentingan kaum pemodal. Perkembangan dunia pendidikan di Indonesia tidak dapat dilepaskan dari pengaruh perkembangan globalisasi, apalagi menyangkut dengan situasi pendidikan yang banyak berorientasi dengan masalah mahalnya biaya pendidikan sekarang. Selain itu, era pasar bebas juga merupakan tantangan baru bagi dunia pendidikan Indonesia, karena terbuka peluang lembaga pendidikan dan tenaga pendidik dari mancanegara masuk ke Indonesia.

Tiga dampak kapitalisme terhadap pendidikan yaitu 1) Hubungan antara kapitalisme dan pendidikan urban menyebabkan praktek-praktek sekolah yang lebih mendukung control ekonomi oleh kelas-kelas elit.2) Hubungan antara kapitalisme dan ilmu pengetahuan telah mendorong berkembangnya ilmu pengetahuan yang hanya bertujuan mendapatkan profit material disbanding untuk menciptakan kehidupan global yang lebih baik.3) perkawinan antara kapitalisme dan pendidikan dan kapitalisme dan ilmu pengetahuan telah menciptakan pondasi bagi ilmu pendidikan yang menekankan nilai-nilai korporasi dengan mengorbankan nilai-nilai keadilan social dan martabat kemanusiaan.

Persoalan mahalnya biaya pendidikan sebagai akibat adanya komersialisasi pendidikan bukan lagi menjadi masalah baru, mulai dari biaya pendaftaran masuk sekolah dijenjang pendidikan Sekolah Menengah Pertama hingga Perguruan Tinggi. Permasalahan tersebut merupakan persoalan klasik yang selalu hadir dari tahun ke tahun terutama menjelang tahun ajaran baru dimulai. Namun, persoalan mengenai besarnya biaya pendidikan yang timbul tidak dapat dianggap persoalan yang kecil, karena masalah tersebut menyangkut keadilan dan hak bagi seluruh anggota masyarakat untuk bersamasama mendapat pendidikan yang bermutu dan berkualitas. Akibatnya masyarakat yang mempunyai penghasilan dibawah rata-rata tidak bisa melanjutkan pendidikan yang lebih tinggi. Hal ini seperti yang dialami oleh Asma dan Mia yang tidak mampu melanjutkan pendidikannya ke jenjang yang lebih tinggi karena alasan pendidikan sekarang yang mahal.

Kurangnya kesempatan masyarakat untuk melanjutkan pendidikan ke jenjang yang lebih tinggi secara tidak langsung telah membuktikan bahwa rantai kemiskinan semakin mustahil diputuskan oleh pendidikan. Secara sederhana, rantai kemiskinan dapat digambarkan karena miskin orang tidak dapat sekolah, karena tidak sekolah, seseorang tidak dapat pekerjaan yang baik karena tidak dapat pekerjaan sehingga menjadi miskin 
begitu seterusnya. Pendidikan sebagai alat pemberdayaan yang dapat memutus rantai kemiskinan semakin kehilangan fungsinya.

\section{KESIMPULAN}

Bentuk komersialisasi pendidikan yang terjadi yaitu biaya pendidikan mahal yang tidak dapat dijangkau oleh masyarakat apalagi yang berasal dari kelas sosial bawah, biaya pendidikan mahal yang tidak mengenal tingkatan atau jenjang pendidikan, baik jenjang pendidikan terendah maupun tertinggi. banyaknya pungutan-pungutan diluar pungutan wajib seperti buku-buku pelajaran, peringatan-peringatan hari besar nasional, maupun kegiatan-kegiatan di luar sekolah menjadi salah satu penyebab masyarakat semakin mengeluh dengan biaya pendidikan yang semakin mahal dari jenjang pendidikan terendah hingga tertinggi.

Dampak adanya komersialisasi pendidikan dibagi menjadi dampak positif dan negatif yaitu :

a. Dampak Positif yaitu beban pemerintah membiayai pendidikan semakin berkurang sebab banyaknya pungutan-pungutan yang ditarik lembaga-lembaga pendidikan, baik pungutan wajib maupun tidak wajib, menambah keuntungan dan pemasukan kas lembaga pendidikan karena biaya pendidikan mahal serta banyaknya pungutanpungutan sehingga secara tidak langsung lembaga pendidikan memperoleh profit (keuntungan). Lembaga pendidikan semakin kompetitif meningkatkan fasilitas dan mutu pendidikan untuk menarik peminat yang banyak sehingga biaya pendidikan semakin mahal.

b. Dampak Negatif yaitu Pendidikan semakin mahal tidak mengenal jenjang pendidikan, baik jenjang pendidikan tertinggi maupun terendah serta semakin banyaknya pungutan-pungutan yang dilakukan lembaga pendidikan, Pendidikan sebagai ladang bisnis menjadi trend di dunia pendidikan, pendidikan diibaratkan pasar atau supermarket yang menyediakan berbagai barang untuk para pelanggan, sedangkan pendidik (guru atau dosen) sebagai kasir yang selalu melayani pelanggan yaitu peserta didik, Gejala stigmatisasi dan diskriminasi antara kaya dan miskin berdampak bagi yang kurang mampu untuk memperoleh pendidikan layak, Rantai kemiskinan sulit diputuskan melalui pendidikan, Tercipta privatisasi pendidikan sehingga memberikan hak otonomi kepada lembaga pendidikan untuk mengurus anggaran lembaga pendidikan yang dikelola, perubahan misi pendidikan dari budaya akademik menjadi budaya ekonomi. 


\section{DAFTAR PUSTAKA}

Darmaningtyas, (2004). Pendidikan yang Memiskinkan, Yogyakarta: Galang Press,

Departemen Pendidikan Nasional. (2003).Undang-Undang Nomor 20 tahun 2003 : tentang System Pendidikan Nasional. Jakarta : Departemen pendidikan nasional.

Emzir, (2012). Metodologi penelitian kualitatif, Jakarta: Rajawali pers : Pt.Raja Grafindo Persada.

Engkoswara. (2001). Paradigma Manajemen Pendidikan Menyongsong Otonomi Daerah (Terjemahan ). Bandung: Yayasan Amal Keluarga.

Freire, Paulo. (2002). Politik Pendidikan, Kebudayaan Kekuasaan dan Pembebasan, Jakarta: Pustaka Pelajar.

Giddens, Anthony. (2007) . Karsidi, Ravik, 2005. Sosiologi Pendidikan (LPP) US dan UPT.Surakarta

Mead dan Blumer. (2010). Teori sosiologi modern (Terjemahan, teori interaksionisme simbolik). Jakarta : Kencana

Nisa,Hamidatun. (2009) Potret Komersialisasi dan Hilangnya Pemenuhan Hak Ekonomi , Social Dan Budaya Siswa. Skripsi Fakultas ISIP UMM.Malang: (tidak diterbitkan)

Nugroho Riant dan H.A.R.Tilaar. (2008). Kebijakan Pendidikan, Pengantar Untuk Memahami Kebijakan Pendidikan dan Kebijakan pendidikan Sebagai Kebijakan Publik, Yogyakarta: Pustaka Pelajar,

Pidarta, (2009). Sosiologi pendidikan, Jakarta : direktorat jenderal pendidikan tinggi departemen pendidikan nasional

Prasetyo, Eko. (2005). Orang Miskin Dilarang Sekolah, Yogyakarta: Resist Book,

Soetjipto, Tantangan. (2000). Kebijaksanaan dan Manajemen pendidikan Tinggi ( Terjemahan ), Universitas Negeri Jakarta.

Tilaar H.A.R.,.(2012). Perubahan sosial dan Pendidikan. Jakarta: Rineka Cipta

Tukijan Eddy, Dkk.(2009). Sosiologi Pendidikan. Jakarta: Rineka Cipta

Wibowo, Agus. (2008). Malpraktik Pendidikan, Yogyakarta: Genta Press

Yamin, Moh. (2009). Menggugat Pendidikan Indonesia: Belajar dari Paulo Freire dan Ki Hajar Dewantara, Yogyakarta: Ar-Ruzz Media. 